\title{
Eğitim ve Araştırma Hastanesinde Denetimli Serbestlik Uygulamalarının Değerlendirilmesi
}

\author{
Evaluation of Probation Implementations in Training and Research Hospital
}

\author{
Murat Aslan ${ }^{1}$, Ciçek Hocaoğlu ${ }^{2}$
}

${ }^{1} U z m$. Dr., Şanlıurfa Mehmet Akif İnan Ĕ̈itim ve Araştırma Hastanesi Psikiyatri Kliniği, Şanlıurfa

${ }^{2}$ Prof.Dr., Recep Tayyip Erdoğan Üniversitesi Tip Fakültesi, Psikiyatri Anabilim Dall, Rize.

\section{Özet}

Amaç: Denetimli serbestlik (DS), kişinin işlediği bir suç sebebiyle tutuklanması ya da mahkemece hakkında mahkûmiyet kararı verilmesi sonucunda cezaevine girmesi yerine, cezasinı toplum içerisinde gözetim ve denetim altında çekmesini ifade etmektedir. Buna göre DS uygulamasının bir çeşit infaz sistemi olduğu söylenebilir. Bu çalışmada DS yasası kapsamında hastanemize başvuran kişilerin sosyo-demografik özellikleri, DS uygulamalarının sonuçları ile olguların tedavi uyumlarının değerlendirilmesi amaçlanmıștır.

Gereç ve Yöntem: Çalışmaya 01.04-15.11.2013 tarihleri arasında haklarında DS kararı verilip Recep Tayyip Erdoğan Üniversitesi Eğitim ve Araştırma Hastanesi DS Birimi'ne başvuran 200 olgu dâhil edilmiştir. Bu olguların 13'ü cezaevinden, 187'si de toplumda yaşayan kişilerden oluşmaktadır. DS uygulaması en az bir kez psikiyatrik görüşme ve idrarda psikoaktif madde değerlendirmesi, üç haftalık ve altı haftalık programlar dâhilinde gerçekleştirilmiştir. Ruhsal değerlendirme için gönderilen olgular ise DS şubelerince belirlenen süre çerçevesinde aylık görüşmelerle takip edilmiştir.

Bulgular: Bu çalışma sürecinde toplam 200 olgunun DS tedbirince başvurduğu saptanmıştır. Olguların ikisi kadın ve 198 ’ erkektir. Yaş ortalaması $32.5 \pm 9.8$ (18-69) olarak saptanmıştır. Üç haftalık programı 46 (\%23.0) olgunun, altı haftalık programı on olgunun (\%5.0) tamamladığı, 25 olgunun (\%12.5) ise tedaviye uyumsuzluk gösterdiği belirlenmiştir. Çalışmamızda 64 (\%32.0) olgu, cezaevi yerine toplum içerisinde takip ve tedavisini tamamlamıștır.

Tartışma ve Sonuç: DS yasası kapsamında hastaneye başvuranların sayısı her geçen gün gittikçe artmaktadır. Bununla birlikte, bu bireylere kendi yerleşim merkezlerinde daha kolay ulaşabilecekleri tedavi programlarını kullanabilme imkânlarının sağlanabilmesi adına DS tedavi programını uygulayabilecek asgari koşullara sahip hastanelerin sayıları artırılmadan ve gerekli alt yapıları oluşturulmadan söz konusu uygulamanın bazı sıkıntıları da beraberinde getireceği çok açıktır. Özellikle, tedavi kurallarına uyum sorunu yaşanması veya verilen raporla hastanın hapis cezası alabileceği gibi durumlarda hekimler ve diğer görevli personel öfkenin hedefi haline gelebilmektedir. Ülkemizde DS uygulamalarının standardizasyonu için ilgili düzenlemelerin yapılması, raporların tek hekim yerine sağlık kurulu tarafından verilmesi ve görev yapacak sağlık çalışanlarının eğitimi gereklidir.

Anahtar kelimeler: Denetimli serbestlik uygulaması, Psikoaktif madde kullanımı, Sosyodemografik özellikler, Tedavi uyumu.

\section{Abstract}

Objective: Probation implementation means criminals serve their sentences under surveillance and control inside the society instead of being sent to prison as a result of an imprisonment verdict given by a judge after they commit a crime. According to this, it can be said that probation is a kind of an execution system. It is aimed to evaluate the socio-demographic characteristics of the people who applied to our hospital within probation law and the treatment coherence of the cases according to the results of probation implementation.

Materials and Methods: Two hundred cases, applying to Recep Tayyip Erdoğan University, Training and Research Hospital, all of whom were decided to have probation implementation on 01.0415.11.2013 were included in the study. These cases consist of people, 13 of whom were from prison and 187 of whom were living out in the society. Probation implementation was carried out by having psychiatric interview and evaluating psychoactive substance in urine in three-week and six-week programs. On the other hand, the cases sent for mental evaluation were monthly followed in a period defined by probation implementation branches.

Results: It was determined that totally 200 cases applied as required by Probation implementation during the study. Two of the cases were female, while 198 of them were male. Mean age was determined as $32.5 \pm 9.8$ (18-69). It was also observed that 64 cases (23.0\%) completed three week program and ten cases (5.0\%) completed six week program, but twenty five cases $(12.5 \%)$ showed in congruity to the treatment. Sixty-four cases (32.0\%) completed their follow-up and treatment in the society instead of prison.

Discussion and Conclusion: The number of applicants to the hospital within probation implementation is increasing day by day. However, it is obvious that the mentioned implementation will be accompanying some problems if the number of the hospitals where probation treatment can be implemented, even with minimum conditions is not increased and if there are not any infrastructures. These will provide the individuals with possibility to be treated where they are settled. Especially, the doctors and other staff will be the target of anger in case there is compliance problem or the patient can be sentenced with a medical report. It is required in our country that relevant regulations should be made and medical reports should be given by healthcare commissions instead of an only doctor to provide the standardization of probation implementations. Also, healthcare personnel should be trained.

Keyworlds: Probation implementation, Psychoactive substance use, Socio-demographical features, Treatment compliance.

\section{Giriş}

Recep Tayyip Erdoğan Üniversitesi

Psikiyatri Anabilim Dal, Rize- Türkiye

Tel: 0-464-2174274

E-mail: cicekh@gmail.com

Denetimli serbestlik (DS), kişinin işlediği bir suçtan dolayı tutuklanması ya da mahkemece hakkında mahkûmiyet kararı verilmesi neticesinde cezaevine girmesi yerine, cezasını 
toplum içerisinde gözetim ve denetim altında çekmesi anlamına gelmektedir (1) Başka bir deyimle, uygulama alanı ve sınırları yasalarla belirlenmiş hapis cezasına alternatif bir yöntem olarak modern hukuk sistemlerinden alınarak Türk Ceza Yasası içerisine entegre edilmiş "Şüpheli”, "Sanık” veya "Hükümlü"lerin denetim altında tutulması, takip edilmesi ve ıslah edilmesini amaçlayan ceza uygulamalarıdır. Açık cezaevinde cezasının son altı ayını kesintisiz olarak geçirenler, çocuk cezaevinde ise toplam cezasının beşte birini tamamlayanlar, koşullu salıverilmesine bir yll ve daha az süre kalanlar ile Ceza İnfaz Kurumu'nun iyi halli hükümlü raporu vermesi, talepte bulunulması veya infaz hakiminin karar vermesi durumunda olanlar denetimli serbestlik yasasından yararlanabilmektedir. Uyuşturucu veya uyarıcı madde kullanan kişiler hakkında, tedavi ve denetimli serbestlik tedbirine başvurulabilmektedir $(2,3)$. Toplumda madde bağımlısı olan bireylerin sayısının azaltılmasında ve bunların tedavi edilmesinde DS uygulamasının kişiye katkı sağladı̆̆ı belirtilmiştir (4). Son yıllarda cezaevlerindeki aşırı kalabalıklaşma, fiziksel imkânlardaki yetersizlikler, kısa süreli cezaya mahkum edilen kişilerin sayılarının fazla oluşu ve bunların toplum içinde rehabilite edilmesine yönelik anlayışın yaygınlaşması DS sisteminin uygulanmaya başlamasını zorunlu hale getirmiştir $(5,6)$. Dünyada birçok ülkede uzun süredir uygulanan DS uygulaması, modern anlamda ülkemizde 2005 yılında uygulanmaya başlamıştır. 5237 sayılı Türk Ceza Yasası'nın 191. maddesinde yer alan 'Kullanmak için uyuşturucu ve uyarıcı madde satın almak, kabul etmek veya bulundurmak' suçundan dolayı haklarında DS kararı verilenler ile 5271 sayılı Ceza Muhakemesi Yasası'nın 109. maddesine göre haklarında adli kontrol kararı alınan bireylerin madde bağımlılığı tedavilerinin nasıl yapılacağı açıklanmıştır $(6,7)$. DS uygulamasına dâhil edilen olgu sayısı her geçen yıl hızı bir şekilde artmaktadır. Adalet Bakanlığı DS Daire Başkanlığı verilerine göre; 2006 yılında hakkında herhangi bir suçtan dolayı DS kararı verilen olguların sayısı 15.525 iken, 2013 yılı sonu itibariyle 345.215 olgu olmuştur (8).

DS uygulaması, Adalet ve Sağlık Bakanlıklarının birlikte çalışmalarını gerektiren bir organizasyondur. Öncelikle, Adalet Bakanlığı Cumhuriyet Başsavcılığının ilgili birimi olan Denetimli Serbestlik ve Yardım Merkezi Şube Müdürlükleri (DSYMSSM), hakkında DS programına alınma kararı verilen bireyleri bölgedeki Sağlık Bakanlığının ilgili birimlerine sevk etmektedir. Olgular başlangıçta, bünyesinde psikiyatri uzmanının olduğu ve alınan örneklerin toksikolojik analizlerinin yapılaca $\breve{g}_{1}$ devlet hastanelerine yönlendirilmektedirler. Altıntoprak ve arkadaşlarının yaptıkları bir çalışmada (1), standart bir uygulamanın olmaması neticesinde ortaya çıkan aksaklıklara dikkat çekilmiş ve tüm sağllk kurumlarınca uygulanabilecek standart tedavi programının gerekliliği vurgulanmıştır. Bu amaçla, 2010 yılı nisan ayında Türkiye Psikiyatri Derneği Alkol ve Madde Kullanım Bozuklukları Bilimsel Çalışma Birimi, 'Denetimli Serbestlik Bağımlılık Programı' kılavuzunu yayınlamıştır (9). DS uygulamasının ilk başladığı dönemde yeterli altyapı sağlanamadığı için olguların büyük çoğunluğu Alkol ve Madde Bağımlılığı Tedavi Merkezlerine (AMATEM) yönlendirilmektedir.

$\mathrm{Bu}$ çalışmada DS yasası kapsamında hastanemize başvuranların sosyo-demografik özellikleri, DS uygulamalarının sonuçları ile olguların tedavi uyumlarının değerlendirilmesi amaçlanmıştır.

\section{Gereç ve Yöntem}

$\mathrm{Bu}$ çalışmaya 01.04-15.11.2013 tarihleri arasında haklarında DS kararı verilip sevk tarihinden itibaren beş gün içinde Recep Tayyip Erdoğan Üniversitesi Eğitim ve Araştırma Hastanesi DS Birimi’ne başvuran 200 olgu dâhil edilmiştir. Bu olguların 13’ü cezaevinden çalışmaya dâhil edilmiştir. Bu grup herhangi bir suçtan dolayı tutuklu veya hükümlü olup, madde kullanımı nedeniyle haklarında DS kararı verilen veya haklarında DS uygulamasına gerek olup-olmadığına karar verilmek üzere gönderilen olgulardan oluşturulmuştur. Olguların 187'si ise toplumda yaşayan bireylerden oluşmaktadır. Olguların sosyo-demografik özellikleri ve psikiyatrik bulguları yazılı olarak kaydedilmiştir. Psikiyatrik görüşmeler, psikiyatri asistanı tarafından yapılmış olup gerektiğinde birim sorumlusu öğretim üyesine danışılmıştır. DS uygulaması en az bir kez psikiyatrik görüşme ve idrarda psikoaktif madde değerlendirmesi, üç haftalık ve altı haftalık programlar dâhilinde gerçekleştirilmiştir.

Üç haftalık program dâhilinde 15 gün arayla yapılan idrarda psikoaktif madde analizi değerlendirmesinde; üç idrar analizi sonucunun negatif çıkması durumunda birey maddeden arınmış (erken tam remisyon) olarak kabul edilmiştir. Sonrasında bireyin DS sürecinin DSYMŞM tarafından sürdürülmesi yönünde rapor düzenlenmiştir. Üç haftalık izlem sonucunda idrar analizi en az bir kez pozitif tespit edilenler altı haftalık programa dâhil edilmişlerdir. Bu programda olguların her hafta idrar analizi yapılmış ve haftalık konuları işlenmiştir. İdrar analizi 4, 5 ve 6. haftalar dâhil olmak üzere ardışık olarak en az üç kez negatif tespit edilenler erken tam remisyon olarak değerlendirilmiştir. $\mathrm{Bu}$ olguların da takiplerinin DSYMŞM tarafından sürdürülmesinin uygun olacağı rapor edilmiştir. Üç ve altı haftalık program esnasinda uyum göstermeyen, idrar analizi pozitif olan, şiddetli çekilme ve psikotik belirtilerin gözlendiği veya intihar riskinin eşlik ettiği depresif bozukluğun olduğu durumlarda program sonlandırılmıştır. 
Olguların tedavi amacıyla en yakın AMATEM'e sevk edilmesi için DSYMŞM’ye bildirimde bulunulmuştur.

Olgulardan, ardışık olarak en az üç kez negatif idrar örneği verenler, idrar numunesi verme esnasında görevlilerle sorun yaşamayanlar, psikiyatrik görüşmelere zamanında gelenler, testin güvenilirliğini etkileyecek miktarda su içmeyenler, idrar analizini etkileyebilecek herhangi bir ilaç kullanmayanlar veya kullandıkları tıbbi ilaçları doktor raporu ile belgelendirenler DS programına uyumlu olarak değerlendirilmiştir. Uyumsuzluk gösteren olgular hakkında ilgili DS birimi yazılı olarak bilgilendirilmiş olup, tekrar programa dâhil edilmeye çalışılmıştır.

Altı haftalık program dahilinde olgular, Türkiye Psikiyatri Derneği’nin ilgili biriminin hazırlamış olduğu DS Bağımlılık Programı kılavuzu kriter alınarak değerlendirilmiştir. Bu kılavuz özü itibariyle bir eğitim programıdır. Altı hafta süresince her haftada bir konu işlenmektedir. 1. hafta DS bilgilendirme ve bağımlılık kavramını, 2. hafta uyuşturucu maddeler ve etkilerini, 3 . hafta ise madde kullanımını bırakmaya yönelik motivasyon kazandırma çalışmalarını içermektedir. 4. haftada kişinin duygu, düşünce ve davranışlarını anlamaya ve tekrar madde kullanmaya sevk edebilecek duygularla baş etmesinde yardımcı olunmaya çalışılmaktadır. 5. haftada kişinin tekrar madde kullanmaya başlamasına yönelik önlemler üzerinde çalışılmaktadır. 6. hafta ise madde kullanımını bırakmaya yönelik yapılabilecek davranış değişikliklerini içermektedir.

Bu kılavuza göre olgular madde bağımlılığı ve tedavi süreci hakkında bilgilendirilmiş olup, program boyunca olgulardan her hafta kendilerine verilen ödevleri yapmaları istenmiştir.

Hakkında DS kararı verilen olguların tümü madde kullanıcıları olmayıp ruhsal değerlendirme için gönderilen olgular da bulunmaktadır. Toplam 41 olgu (\%20.5) hiç madde kullanmamıştır. Bunlar arasında cezaevinden çıktıktan sonra takip ve tedavisinin yapılması istenen olgular veya haklarında adli süreç devam ederken psikiyatrik açıdan değerlendirilmesi için gönderilenler mevcuttur. Başlıca değerlendirilen konular olgularda madde kullanımı olup olmadığı, ceza sorumluluklarının belirlenmesi ve psikiyatrik hastalıklar olarak sıralanabilir. Bu olgular DS şubelerince belirlenen süre içerisinde aylık görüşmelerle takip edilmiştir. Bu görüşmeler DSM-5 tanı kriterleri dikkate alınarak yapılmış olup, psikiyatrik tanı konulan olguların - gerektiğinde birim sorumlusuna danışılarak - psikiyatrik tedavilerine başlanmıştır.

\section{Bulgular}

Çalışmaya, belirtilen zaman diliminde DS uygulaması için başvuran 200 kişi dâhil edilmiştir. Katılımcıların ikisi kadın ve 198’i erkektir. Yaş ortalaması $32,5 \pm 9,8$ (18-69) olarak saptanmıştır. Olguların en yoğun yer aldığı yaş grubu 18-30 $(\% 48,0)$ yaş aralığıdır. Eğitim düzeyleri açısından incelendiğinde 80 (\%40.0) katılımcının ilköğretim mezunu olduğu görülmüsstür. 95 (\%47.5) olgunun bekar, 94'ünün (\%47.0) ise evli olduğu tespit edilmiştir. Meslekleri açısından incelendiğinde ise 98 (\%49.0) bireyin işçi olduğu, 31’inin (\%15.5) ise işsiz olduğu gözlenmiştir. Olgular gelir düzeyine göre değerlendirildiğinde; 95’inin (\%47.5) 501-1000 TL kazanc1 olduğu, 42'sinin (\%21.0) ise herhangi bir geliri olmadığ saptanmıştır. 59 olguda ise geçmişte psikiyatrik ilaç kullanım öyküsü tespit edilmiştir (Tablo 1).

Tablo 1. Olguların Sosyo-demografik Özelliklerine Göre Dağılımı.

\begin{tabular}{|c|c|c|}
\hline & $\mathbf{N}$ & $\%$ \\
\hline \multicolumn{3}{|l|}{ Gelis Nedeni } \\
\hline Denetimli Serbestlik & 149 & 74.5 \\
\hline Ruhsal Deḡerlendirme & 51 & 25.5 \\
\hline \multicolumn{3}{|l|}{ Cinsiyet } \\
\hline Kadin & 2 & 1.0 \\
\hline Erkek & 198 & 99.0 \\
\hline \multicolumn{3}{|l|}{ Yas Aralığ } \\
\hline 1830 & 96 & 48,0 \\
\hline $31-40$ & 64 & 32.0 \\
\hline $41-50$ & 29 & 14.5 \\
\hline $51-60$ & 9 & 4.5 \\
\hline 61 ve tistii & 2 & 1.0 \\
\hline \multicolumn{3}{|l|}{ Eğitim Düzeyi } \\
\hline Okur Yazar & 2 & 1.0 \\
\hline Ilkokul & 73 & 36.5 \\
\hline Ilköğretim & 80 & 40.0 \\
\hline Lise & 40 & 20.0 \\
\hline Universite & 5 & 2.5 \\
\hline \multicolumn{3}{|l|}{ Medeni Durum } \\
\hline Bekar & 95 & 47.5 \\
\hline Evli & 94 & 47.0 \\
\hline Dul & 11 & 5.5 \\
\hline \multicolumn{3}{|l|}{ Meslek } \\
\hline Isci & 98 & 49.0 \\
\hline Issiz & 31 & 15.5 \\
\hline Esnaf & 22 & 11.0 \\
\hline Çiftci & 21 & 10.5 \\
\hline Serbest Meslek & 19 & 9.5 \\
\hline Ögrenci & 4 & 2.0 \\
\hline Emekli & 4 & 2.0 \\
\hline Ev Hanımi & 1 & 0.5 \\
\hline \multicolumn{3}{|l|}{ Yașadiğ Yer } \\
\hline II & 121 & 60,5 \\
\hline Iice & 49 & 24.5 \\
\hline Köy & 30 & 15.0 \\
\hline \multicolumn{3}{|l|}{ Gelir Düzeyi (TL) } \\
\hline Yok & 42 & 21.0 \\
\hline $1-500$ & 13 & 6.5 \\
\hline $501-1000$ & 95 & 47.5 \\
\hline $1001-2000$ & 35 & 17.5 \\
\hline $2001-5000$ & 13 & 6.5 \\
\hline 5001 ve Ustü & 2 & 1.0 \\
\hline \multicolumn{3}{|l|}{$\begin{array}{l}\text { Psikiyatrik Tedavi } \\
\text { Öyküsüi }\end{array}$} \\
\hline Var & 59 & 29.5 \\
\hline Yok & 141 & 70.5 \\
\hline Toplam & 200 & 100.0 \\
\hline
\end{tabular}


Çalışma kapsamında değerlendirilen olgular, psikiyatrik tanı dağılımlarına göre değerlendirildiğinde 24 (\%12.0) olguya depresif bozukluk tanısı konmuş olup, 149 (\%74.5) olgu normal psikiyatrik muayene olarak değerlendirilmiştir (Tablo 2).

Tablo 2. Olguların Psikiyatrik Tanılarına Göre Dağılımı.

\begin{tabular}{|l|c|c|}
\hline Psikiyatrik Tam & N & $\%$ \\
\hline $\begin{array}{l}\text { Normal Psikiyatrik } \\
\text { Muayene }\end{array}$ & 149 & 74.5 \\
\hline Depresyon & 24 & 12.0 \\
\hline Şizofreni & 11 & 5.5 \\
\hline $\begin{array}{l}\text { Alkol-Madde } \\
\text { Bağımlilŭı }\end{array}$ & 10 & 5.0 \\
\hline Bipolar Bozukluk & 3 & 1.5 \\
\hline Anksiyete Bozukluğu & 1 & 0.5 \\
\hline Yas Reaksiyonu & 1 & 0.5 \\
\hline Akut Stres Bozukluğu & 1 & 0.5 \\
\hline Toplam & 200 & 100.0 \\
\hline
\end{tabular}

Katılımciların 68’i (\%34.0) 11-20 paket/yıl aralığında sigara kullanmışken, hiç sigara kullanmayanların sayısı sekiz (\%4.0) olarak bulunmuștur. Olguların 57'sinde (\%28.5) 0-5 yıl arasında alkol kullanımı söz konusu iken, 49 (\%24.5) olgunun hiç alkol kullanmadığ 1 tespit edilmiştir. Katılımcılar psikiyatrik öykülerine göre psikoaktif madde kullanımı açısından değerlendirildiklerinde; 141 (\%70.5) olgu, hayatlarının bir döneminde esrar kullandıklarını belirtmişlerdir (Tablo 3).

Tablo 3. Olguların Sigara, Alkol ve Madde Kullanım Öyküleri.

\begin{tabular}{|c|c|c|}
\hline Sigkara Kullanım (Paket/Yul) & $\mathbf{N}$ & $\%$ \\
\hline Hiç Kullanmamış & 8 & 4.0 \\
\hline 0.5 & 48 & 24.0 \\
\hline $5-10$ & 44 & 22.0 \\
\hline 1120 & 68 & 34.0 \\
\hline 2130 & 18 & 9.0 \\
\hline $31-40$ & 6 & 3.0 \\
\hline $41-50$ & 1 & 0.5 \\
\hline 51 ve Ustil & 7 & 3.5 \\
\hline \multicolumn{3}{|l|}{ Alkol Kullanum (Yil) } \\
\hline Hiç Kullianmamıs & 49 & 24.5 \\
\hline 0.5 & 57 & 28.5 \\
\hline $5-10$ & 50 & 25,0 \\
\hline 11.20 & 31 & 15,5 \\
\hline $21-30$ & 9 & 4.5 \\
\hline $31-40$ & 3 & 1.5 \\
\hline 41 ve Ustil & 1 & 0.5 \\
\hline Toplam & 200 & 100.0 \\
\hline Psikonaktif Madde Kullanum (Öyküden) & $\mathbf{N}$ & $\%$ \\
\hline Hiç Kullianmamış & 41 & 20.5 \\
\hline Essar & 141 & 70.5 \\
\hline Ekstazi & 6 & 3.0 \\
\hline Benzoxtiazepin & 3 & 1.5 \\
\hline Kokain & 3 & 1.5 \\
\hline Bonzai & 3 & 1.5 \\
\hline Eroin & 2 & 1.0 \\
\hline Bali & 1 & 0.5 \\
\hline Toplam & 200 & 100.0 \\
\hline
\end{tabular}

Olgular DS tedavi ve uyum düzeyleri açısından incelendiğinde; üç haftalık programı 46 (\%23.0) olgunun tamamladığı, 32'sinin (\%16.0) Samsun Ruh ve Sinir Hastalıkları Hastanesine (RSHH) sevk edildiği ve 19 (\%9.5) olgunun da programa uyum sağlayamadığ tespit edilmiştir. Altı haftalık programı 10 olgunun (\%5.0) tamamladığı, birinin (\%0.5) Samsun RSHH'ye sevk edildiği ve üçünün (\%1.5) de programa uyum sağlayamadığı gözlenmiştir. Takip ve tedavisi devam edenlerden 11'er (\%5.5) olgu da normal psikiyatrik muayene ve depresif bozukluk tanısıla izlenmektedir. Takip ve tedavisi tamamlanan olgulardan altısı (\%3.0) normal psikiyatrik muayene, ikişer (\%1.0) olarak depresyon ve bipolar bozukluk tanılarını almıştır (Tablo 4). Bu çalışmada 64 (\%32.0) olgunun takip ve tedavisi, cezaevi yerine toplum içerisinde tamamlanmıştır.

Tablo 4. Olguların Tedaviye Devamı ve Uyum Düzeyleri.

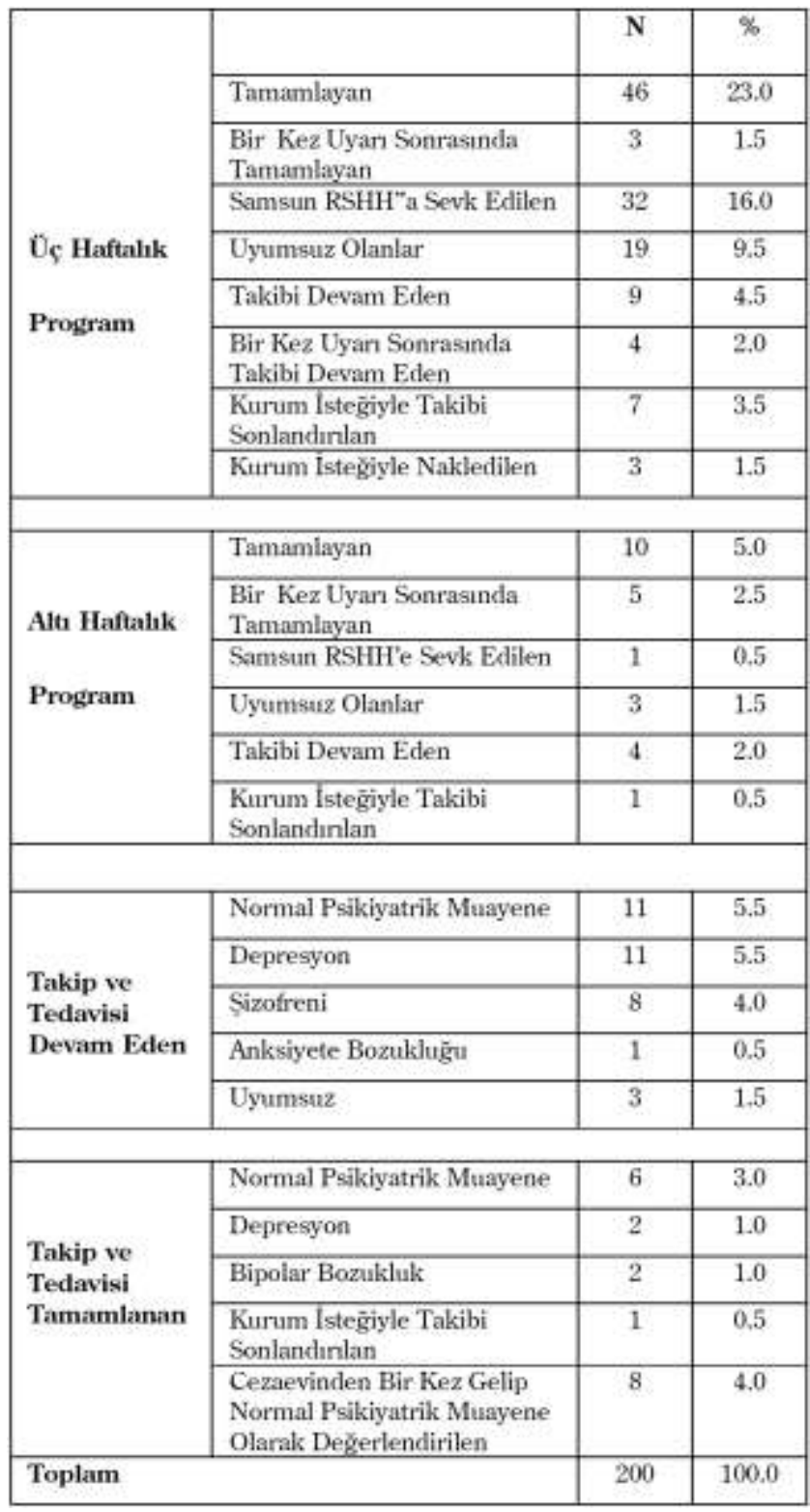




\section{Tartışma}

Bu çalışmada; DS uygulaması dâhilinde hastanemize başvuran olguların sosyo-demografik özellikleri, psikiyatrik tanılara göre dağılımları, sigara, alkol, madde kullanım öyküleri ve DS uygulamalarının sonuçları ile olguların tedavi uyumları değerlendirilmiştir. Ancak yeterli ve deneyimli personelin olmaması, gerekli laboratuar koşullarının, uygulanacak standart bir izlem ve tedavi programının olmaması uygulamada birçok aksaklıklara neden olmuştur. Yaklaşık olarak 10 yıldır ülkemizde uygulanıyor olmasına rağmen, DS uygulaması hakkında yapılmış kısıtlı sayıda çalışma bulunmaktadır. Çalışmamızda olguların tamamına yakınını (\%99) erkekler oluşturmaktadır. Eğitim düzeylerine bakıldığında katılımcıların çoğunluğunun (\%40) ilköğretim mezunu oldukları, il ve ilçe merkezlerinde yaşayanların çoğunlukta (\%85) olduğu, evli (\%47) ve bekar (\%47.5) olguların yaklaşık olarak aynı oranda oldukları tespit edilmiştir. Bu sonuçlar daha önce yapılmış çalışmalarla uyum göstermektedir (10-15).

Çalışmamızda işsiz olan bireylerin oranı \%15.5 olarak bulunmuşken, Zorlu ve arkadaşlarının çalışmasında (12) düzenli işi olmayanların oranı \%39.5 olarak verilmiş ve madde kullanımını etkileyen tek değișkenin ișsizlik olduğu bildirilmiştir. İki çalışma arasında bu kadar yüksek oranda farkın olması düşündürücüdür. Bunun nedenleri arasında Zorlu ve arkadaşlarının çalışmalarını yaptıkları il olan İzmir'in sürekli göç alması ve işsizlik oranının yüksek olması akla gelmektedir. Çalışmanın yapıldığı 2010 yılı itibariyle Türkiye İstatistik Kurumu (TÜIK) verilerine göre İzmir'de ișsizlik oranı \%15.1'dir. Bizim çalışmamızın yapıldığı Rize'de ise 2012 TÜ̇K verilerine göre ișsizlik oranı $\% 5.8$ 'dir ve Türkiye ortalaması olan \%9.8’in altındadır (16). Çalışmamızdaki olguların meslekleri incelendiğinde yaklaşı olarak \%60'nnın işçi ve çiftçi olduğu görülmektedir. Olguların çoğunun düşük gelir düzeyine sahip oldukları ve gelir düzeyi arttıkça olgu sayısının azaldığı görülmektedir.

Olguların yaş ortalaması $32.5 \pm 9.8$ olup, olguların en yoğun bulundukları yaş aralığ 18 -30 olarak tespit edilmiştir. Bulgular, yurt dışında ve ülkemizde yapılan benzer çalışmalarla uyum göstermektedir $(13,17)$.

Çalışmamız, Bilici ve arkadaşlarının Elazığ'da yaptıkları çalışma (18) ile karşılaştırıldığında bazı yönlerden benzerlik göstermektedir. Hayatında bir dönem sigara içen ve hala içmekte olanların oranı çalışmamızda \%96 iken, Bilici ve arkadaşlarının çalışmasında \%89 bulunmuştur. Çalışmamızda geçmiş dönemde psikiyatrik tedavi öyküsü alanların oranı \% 29.5 iken, Bilici ve arkadaşlarının çalışmasında \%14.8 bulunmuştur. Yaşamının bir döneminde alkol kullananların oranı \%75.5 iken, Altıntoprak ve arkadaşlarının DS olgularılla yaptıkları çalışmada (13) olguların \%64.3’ünde alkol kullanım bozukluğu tespit edilmiştir. Çalışmamızda; olgulardan alınan öyküye göre en fazla kullanılan madde, esrar olarak tespit edilmiştir. Bu durum literatür bilgisiyle uyum sağlamaktadır (9, 19-21). Çalışmamıza dahil edilen $41(\% 20.5)$ olguda ise, herhangi bir madde kullanımı saptanmamıştır. Ekstazi, eroin ve diğer maddelerin kullanım oranları esrara göre göreceli olarak düşük bulunmuştur. Bunun nedeni bölgemizde bu maddelere ulaşım güçlükleri ve ekonomik nedenlerle açıllanabilir.

DS uygulaması nedeniyle hastaneye yönlendirilen olguların sayısında zamanla önemli oranda bir artış gözlenmiştir. Bununla birlikte, bu kișilerin yaşadıkları bölgelere yakın mesafede ve daha kolay ulaşabilecekleri tedavi programlarını kullanabilme imkânlarının sağlanabilmesi adına DS tedavi programını uygulayabilecek asgari koşullara sahip hastanelerin sayıları artırılmadan ve gerekli alt yapıları oluşturulmadan önce söz konusu uygulamanın bazı sıkıntıları da beraberinde getireceği çok açıktır.

Bu sikıntılardan bir tanesi takip ve tedavi programının maddi yönüdür. Uygulanan DS programına göre; başvuran olgular adli olgular olup, sağlık güvencesi olmayanlardan herhangi bir ücret talep edilmemektedir. Öyle ki, AMATEM birimlerine madde bağımlılı̆̆ tedavisi amacıyla başvuran bireylerin önemli bir kısmının sağlık güvencesi bulunmamaktadır. Zorlu ve arkadaşlarının çalışmasındaki olguların yaklaşık sadece \%40'ının, Bilici ve arkadaşlarının çalışmasında ise yaklaşık \%50'sinin sağlı güvenceleri vardır $(12,18)$. Madde bağımlılarının önemli bir kısmının düzenli geliri olmaması veya düşük gelirli olmaları tedavinin tamamlanmasında önemli bir engel oluşturmaktadır.

Çalışmamızda uyumsuzluk gösteren olguların oranı \%12.5 iken, Altıntoprak ve arkadaşlarının çalışmasında (13) \%10.1'dir. Özellikle, tedavi kurallarına uyum sorunu yaşanması veya verilen raporla bireyin hapis cezası alabileceği durumlarda hekimler ve diğer görevli personel öfkenin hedefi haline gelebilmektedir. Hastanemizde de olguların kendi idrarı yerine başkasının idrarını vermeye çalıșma, idrarını veremediği gerekçesiyle programı aksatma girișimi veya idrar test sonuçlarının yanlış olduğuna yönelik iddialardan dolayı zaman zaman sorunlar yaşanmıştır. Hastanemizde DS olguları için oluşturulmuş bir sağlık kurulu mevcut olmayıp, raporlar sorumlu olan tek öğretim üyesinin imzasıyla çıkmaktadır. Ülkemizde DS uygulamalarının standardizasyonu için ilgili düzenlemelerin yapılması, raporların tek hekim yerine sağlık kurulu tarafından verilmesi ve görev alacak sağlık çalışanlarının eğitimi gereklidir (22).

DS programının uygulanmasındaki bir diğer sorun da katılımcıların DS merkezlerine olan uzaklıklarıdır. Akpınar ve 
arkadaşlarının bu konuyla ilgili yaptıkları çalışmada (10); Samsun RSHH DS Birimine 2010 yılı içinde 492 olgu başvurmuş olup, olguların 219’u Samsun il merkezi ve ilçelerinden, 273'si çevre illerden başvurduğu tespit edilmiştir. Samsun il merkezi dışından başvuran olguların karşılaştırılmalarında; genel itibariyle Rize, Trabzon ve Gümüşhane gibi Samsun'a uzak olan illerden yapılan başvurularda tedaviyi aksatma ve tedaviye uyumsuzluk oranları anlamlı oranda yüksek bulunmuştur.

Çalışmamızda üç ve altı haftalık programlarla ruhsal takip ve tedavisi tamamlanan olguların oranı \%41.5 iken, Altıntoprak ve arkadaşlarının çalışmasında (1) \%46.5 bulunmuştur. Böylece bu olguların erken tam remisyona girmeleri sağlanıp, AMATEM'lerde oluşabilecek aşırı hasta yükü azaltılmaya çalışılmıştır.

Sonuç olarak; madde kullanımının dünyada ve ülkemizde giderek yaygınlaştığı görülmektedir. Bu durumu önlemek için denetimli serbestlik uygulamasının, madde kullanımın takip ve tedavisinde etkili olduğu görülmektedir. Bu programı uygulayan merkezlerin ülke çapında yaygınlaştırılmasının gerekli olduğu düşünülmektedir.

\section{Kaynaklar}

1. Altıntoprak AE, Akgür SA, Coşkunol H. Yasa dışı madde kullanımı nedeniyle denetimli serbestlik tedbiri uygulanan kișilerde tedavi uygulamaları ve toksikolojik analiz. Türkiye'de Psikiyatri 2007:9:166-72

2. Usta İ, Öztürk H. Denetimli Serbestlik. Ceza Hukuku Dergisi 2010;13:1-44

3. Yavuz HA. Denetimli Serbestliğin Türk Ceza Adalet Sistemindeki tarihsel gelişim süreci. Türkiye Barolar Birliği Dergisi 2012;100:318-42.

4. Perry AE, Darwin Z, Godfrey C, McDougall C, Lunn J, Glanville J at al. The effectiveness of interventions for drug-using offenders in the courts, secure astablishments and the community: A sysmatic review. Subst Use Misuse 2009;44:374-400.

5. Evren C. Yasa dışı madde kullananlarda denetimli serbestlik: Psikiyatrik izleme süreci. Psikiyatride Güncel 2011;1(1):26-39.

6. Çolak H, Altun U. Denetimli serbestlik kavramının yaptırım teorisi ve penolojik bakımdan tahlili ile pozitif hukukumuzdaki düzenlemeler, 2006. http://www.yayin.adalet.gov.tr /adaletdergisi/25.sayi/09_27_16.htm. Erişim tarihi:22.02.2015.

7. Usta İ, Öztürk H. Denetimli Serbestlik. Ceza Hukuku Dergisi 2010;13(2):10-2. http://www.cteds.adalet.gov.tr/menusayfalari /bilgibankasi/makaleler/makale_ds_cezahukukudergisi.pdf. Erișim tarihi: 22.02.2015.

8. http://www.cte-dsm.adalet.gov.tr. Erişim tarihi: 22.02.2015
9. Ögel K, Karadağ F, Can Y, Altıntoprak E, Çoşkunol H. Denetimli serbestlik bağımlılık programı. Türkiye Psikiyatri Derneği Yayınları, 2010.

10. Akpınar A, Şalış O, Aksoy UM. Samsun Ruh Sağlı̆̆ı ve Hastalıkları Hastanesi'nde Denetimli serbestlik 2010 yılı sonuçları ve şehir merkezi dışından başvurularda tedavi uyumlarının değerlendirilmesi. Düşünen Adam The Journal of Psychiatry and Neurological Sciences 2013;26(1):46-54.

11. Turan R, Yargic I. The relationship between substance abuse treatment completion, sociodemographics, substance use characteristics, and criminal history. Subst Abus 2012;33(2):92-8.

12. Zorlu N, Türk H, Manavgat Aİ, Karadaş B, Gülseren Ş. Denetimli serbestlik uygulaması kapsamında başvuran hastalarda sosyodemografik, klinik özelliklerin ve alkol kullanım bozukluğu sıklığının geriye dönük değerlendirilmesi. Anadolu Psikiyatri Dergisi 2011;12:253-7.

13. Altıntoprak AE, Akgür SA, Kitapçığlu G, Yüncü Z, Coşkunol H. Denetimli serbestlik olgularının retrospektif analizi: Sosyodemografik özellikler, bireysel ve ailesel bağımlılık ve suç öyküleri ile tedavi yanıtları. Bağımlılık Dergisi 2014;15(1):1-9.

14. Bahçeci B, Çelik FH, Kandemir G, Güveli H, Polat S, Hocaoğlu Ç. Doğu Karadeniz Bölgesi'nde bir eğitim ve araştırma hastanesine denetimli serbestlik kapsamında başvuran hastaların değerlendirilmesi: Bir yıllık geriye dönük çalışma. Adli Tıp Dergisi 2014;8(1):1-9.

15. Ada Ş, Peker A. Tedavi ve Denetimli Serbestlik Tedbiri Uygulamasının etkililiğinin incelenmesi (Sakarya İli örneği) Atatürk Üniversitesi Sosyal Bilimler Enstitüsü Dergisi 2012;16(1):425-38

16. www.tuik.gov.tr. Erişim tarihi: 22.02.2015.

17. Adams BS, Olson DE, Adkins R. Results from the 2000 Illinois adult probation outcome study 2002. Retrieved Marhc 2008, http://www.icjia.state.il.us/public/pdf/ResearchReports/2000Pr obation\%20Outcome\%20 Study.pdf

18. Bilici R, Namlı M, Tufan E, Şafak S. Bir bölge hastanesi AMATEM kliniğine denetimli serbestlik kapsamında başvuran hastaların sosyo-demografik ve klinik özellikleri. 7. Ulusal Alkol ve Madde Bağımlılı̆̆g Kongresi Özet Kitabı, 8-11 Aralık 2011, Belek, Antalya.

19. Akgoz S, Akkaya C, Berkay F, Turkmen N, Kan I,Kirli S. Trends in the annual incidence rates of narcotics felons arrested over the last 30 years in metropolitan Bursa, Turkey. Tohoku J Exp Med 2007;212(3):253-63.

20. Macfadden W, Woody GE. Cannabis-related disorders. ComprehensiveTextbook of Psychiatry. 7th ed. vol. 1, Philadelphia: Lipincott\& Williams, 2000:990-9.

21. Çöpoğlu ÜS, Bülbül F, Kokaçya MH, Alıc1 D, Taştan MF, Ünal Ave ark. Adli psikiyatri polikliniğinde değerlendirilen olguların psikiyatrik tanıları, madde kullanım durumları, sosyo-demografik ve klinik özellikleri. New/Yeni Symposium 2014;52(1):1-6.

22. Karadă̆ F, Can Y, Altıntoprak E. Türkiye Psikiyatri Derneği alkol madde kullanım bozuklukları bilimsel çalışma birimi denetimli serbestlik uygulamalarının standardizasyonu görev grubu raporu. Türkiye Psikiyatri Derneği Bülteni 2008;11:47-55. 